www.volsu.ru

DOI: https://doi.org/10.15688/nav.jvolsu.2021.1.5

UDC 903.3

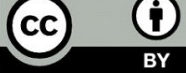

LBC 63.442.7(2)

Submitted: 15.07 .2020

Accepted: 27.05.2021

\title{
SCYTHIAN BRACELETS AND RINGS WITH PROTRUSIONS FROM THE CEMETERY NEAR GLINOE VILLAGE
}

\author{
Svetlana S. Lysenko \\ Institute of Archaeology, National Academy of Sciences of Ukraine, Kiev, Ukraine
}

\begin{abstract}
The article examines bracelets and rings of the La-Tene style from Scythian burials of the cemetery near the Glinoe village, Slobozeya district, on the left bank of the Dniester. Bracelets were found in three burials belonging to different kurgan groups (Glinoe-"Sad", kurgan 8, burial 5; Glinoe-"Vodovod", kurgan 16, burial 6; Glinoe, kurgan 71, burial 1). Single rings with protrusions were found in two burials (Glinoe-"Sad", kurgan 8, burial 2; Glinoe-"Vodovod", kurgan 7, burial 2). Two chains of double rings and one chain of the triple rings of the La Tene style comes from burial 3 of kurgan 14 of the Glinoe-"Vodovod" cemetery. The author considers the typological attribution of these objects according to existing classification, concerns the issue of their manufacturing and dating, as well as the nature of using. Bracelets with protrusions in the form of rosettes of two, three and four ledges from the Glinoe cemetery were likely produced by lost-wax casting. Taking in account the small number of such bracelets found in the North Black Sea region, it is still difficult to draw an unambiguous conclusion about their local production. All researchers agree on the dating of such bracelets in the second half of the $4^{\text {th }}-$ the beginning of the $3^{\text {rd }}$ centuries BC. The purpose of the items analyzed appears obvious. They were worn by women and children. The dating of rings with single, double and triple protrusions almost matches the dating of bracelets of the same type. They were common in the $4^{\text {th }}-$ the beginning of $3^{\text {rd }}$ centuries BC. There is data allowing to consider those bracelets have been used in complex necklaces.

Key words: Lower Dniester region, Scythian culture, adornments of the of the La-Ten style, bracelets, rings.

Citation. Lysenko S.S., 2021. Skifskie braslety i kol'tsa s vystupami iz mogil'nika u sela Glinoe [Scythian Bracelets and Rings with Protrusions from the Cemetery Near Glinoe Village]. Nizhnevolzhskiy Arkheologicheskiy Vestnik [The Lower Volga Archaeological Bulletin], vol. 20, no. 1, pp. 69-81. DOI: https://doi.org/10.15688/ nav.jvolsu.2021.1.5
\end{abstract}

УДК 903.3

Дата поступления статьи: 15.07.2020

ББК $63.442 .7(2)$

Дата принятия статьи: 27.05.2021

\section{СКИФСКИЕ БРАСЛЕТЫ И КОЛЬЦА С ВЫСТУПАМИ ИЗ МОГИЛЬНИКА У СЕЛА ГЛИНОЕ}

\author{
Светлана Станиславовна Лысенко \\ Институт археологии Национальной академии наук Украины, г. Киев, Украина
}

\begin{abstract}
Аннотация. Статья посвящена браслетам и кольцам латенского стиля из скифских погребений курганного могильника у с. Глиное Слободзейского района на левобережье Нижнего Днестра. Браслеты обнаружены в трех погребальных комплексах, относящихся к разным курганным группам (Глиное-Сад, кург. 8, погр. 5; Глиное-Водовод, кург. 16, погр. 6; Глиное, кург. 71, погр. 1). Одиночные кольца с выступами найдены в двух погребениях (Глиное-Сад, кург. 8, погр. 2; Глиное-Водовод, кург. 7, погр. 2). Из одного комплекса (Глиное-Водовод, кург. 14, погр. 3) происходят две цепочки из сдвоенных и одна из строенных колец латенского стиля. Автор рассматривает типологическую принадлежность этих вещей по существующим типологиям, касается вопроса их изготовления и датировки, а также характера использования. Глинянские браслеты с выступами в виде розеток из двух, трех и четырех выпуклин изготовлены, видимо, методом литья по восковой модели. А учитывая небольшое количество браслетов такого типа в Северном () Причерноморье, на наш взгляд, пока сложно делать однозначный вывод об их местном производстве. Все
\end{abstract}


исследователи сходятся на датировке таких браслетов второй половиной IV - началом III в. до н.э. Назначение рассматриваемых изделий не оставляет сомнений - их носили на руках женщины и дети. Датировка колец с одинарными, сдвоенными и строенными выступами практически совпадает с датировкой браслетов такого же типа - IV - начало III в. до н.э. Есть данные для того, чтобы говорить об использовании их в сложносоставных ожерельях.

Ключевые слова: Нижнее Поднестровье, скифская культура, украшения латенского стиля, браслеты, кольца.

Цитирование. Лысенко С. С., 2021. Скифские браслеты и кольца с выступами из могильника у села Глиное // Нижневолжский археологический вестник. Т. 20, № 1. С. 69-81. DOI: https://doi.org/10.15688/ nav.jvolsu.2021.1.5

\section{Введение}

Днестровской археологической экспедицией Приднестровского государственного университета много лет велись раскопки скифских курганов у с. Глиное Слободзейского района на левобережье Нижнего Днестра. Могильник состоит из нескольких курганных групп. В погребальных комплексах, относящихся к разным курганным группам, были найдены украшения в виде литых бронзовых колец с выступами на наружной стороне. Выступы отлиты вместе с изделием и могут быть одинарными, сдвоенными, строенными и счетверенными. Расположены выступы (или группы выступов) на равном удалении друг от друга. Изделия с такими выступами обычно относят к украшениям латенского стиля (или типа). Выступающие элементы исследователи называют по-разному - выступы, шишечки, шарики, выпуклины и т. д. Образованную из этих элементов группу называют гроздью, пирамидкой или розеткой. На Глинянском могильнике три таких изделия являются браслетами, а остальные - кольцами-подвесками.

\section{Браслеты}

Самым большим изделием такого типа здесь оказался браслет из погребения Глиное-Сад, кург. 8, погр. 5. Это основное погребение в кургане, отнесенное к скифской культуре. Браслет обнаружен на правом предплечье женщины 40-50 лет [Синика и др., 2018 a, с. $84-86$, рис. $6,1,7,1]$ (рис. 2,4 ).

Браслет бронзовый, цельнолитой, линзовидный в сечении. С трех сторон украшен группами из четырех уплощенных выступов, скомпонованных ромбом. Диаметр браслета 7,2 см; внутренний диаметр - $6,2 \times 6,5$ см. Сечение браслета $-7 \times 3-7,5 \times 5$ мм. Общие размеры выступов $-2,2 \times 1,3 \times 1$ см (рис. 1,6). Еще один браслет происходит из погребения Глиное-Водовод, кург. 16, погр. 6. Погребение скифское, основное для третьей насыпи. Браслет был надет на левую руку ребенка [Синика и др., 2018б, с. 70, рис. 69,1,3] (рис. 2,2).

Браслет бронзовый цельнолитой, подокруглый в сечении. На почти равном удалении друг от друга на внешней стороне браслета расположены группы приплюснуто-шаровидных шишечек. С двух сторон расположено по три шишечки; с одной - две. Четвертая группа отсутствует из-за явного литейного брака. Возможно, нехватка третьей шишечки на предыдущем выступе тоже связана с литейным браком. Диаметр браслета $5,1 \times 5$ см; внутренний диаметр - 3,85 × 4,2 cм. Сечение браслета $-5 \times 4-5,5 \times 5$ мм; в месте брака литья $-3 \times 4$ мм. Общая ширина розеток из шишечек $-1,1 \times 1,15 \mathrm{~cm}$, диаметры шариков - до 6-7 мм (рис. 1,4).

Третий браслет найден в погребении Глиное, кург. 71, погр. 1. Погребение скифское, основное. Браслет был найден на костях правой руки женщины 15-20 лет [Тельнов и др., 2016 , с. $432-437$, рис. 245,11$]$.

Браслет бронзовый цельнолитой, округлый в сечении. На внешней стороне обода на равном расстоянии расположены четыре группы спаренных приплюснуто-шаровидных шишечек (с одной стороны вторая шишечка не долита и на ее месте прослеживается лишь незначительное утолщение). Диаметр браслета $6,58 \times 6,22$ см; внутренний диаметр $5,72 \times 5,33$ см. Сечение браслета $4,5 \times 4-$ 4,8 $\times 5,2$ мм (рис. 1,5).

Браслеты, аналогичные нашим, известны на скифских памятниках Восточной Европы, хотя и не являются массовым материалом. Наиболее близкие аналогии глинянским изделиям - браслеты из Крихана Веке 5/5 
[Ciobanu et al., 2019, p. 95, fig. 25,1,2] - здесь найдены два браслета этого типа - один с четырьмя розетками из счетверенных выступов, а другой - с тремя розетками из строенных выступов (рис. 3,1-2). Еще одна похожая пара браслетов была найдена в Окна Сибиулуй: один - с тремя розетками из строенных выступов, другой - с тремя розетками из счетверенных выступов [Glodariu, 1984, p. 66; Zirra, 1971, abb. 3,11] (рис. 3,5). Также близок браслет, случайно найденный на могильнике Муригиол [Бужор, 1958, с. 136, рис. 7,11] - у него тоже три розетки из строенных шариков (рис. 3,4).

В.Г. Петренко отнесла подобный браслет из совхоза «Красный Перекоп» (23/1) к типу 11 - браслеты латенского типа, выполненные из круглого или сегментовидного в сечении литого стержня, снабженного по наружной поверхности различными выступами [Петренко, 1978, с. 55, табл. 44,15], подчеркивая, что это редкий тип. Однако к этому типу исследовательница относит, на наш взгляд, совершенно разнотипные браслеты, среди которых только один упомянутый экземпляр близок к глинянским (рис. 3,3).

Е.С. Нефедова расширяет хронологические рамки латенских изделий и называет их гальштатско-латенскими. Она предлагает более подробную классификацию браслетов гальштатско-латенского круга, выделяя среди них 8 типов. Рассматриваемые нами браслеты она относит к типу 8 - несколько шишечек (от 2 до 5) образуют розетку [Нефедова, 1992 , с. 22 , рис. $2,8,14]$.

Принято считать доказанным местное производство подобных браслетов в связи с находкой половинки литейной формы в Ольвии [Фурманська, 1958, с. 48; Петренко, 1978, с. 55; Полин, 2014, с. 73] (рис. 5,3). Но Ольвия была крупным морским торговым центром, поэтому литейная форма могла быть завезена издалека. Кроме того, рассматриваемые нами изделия, видимо, изготовлялись по восковой модели, а не в двустворчатой литейной форме. Да и небольшое количество браслетов такого типа, на наш взгляд, пока не позволяет сделать однозначный вывод об их местном производстве.

В.Г. Петренко датирует выделяемый ею тип 11 второй половиной IV - началом III в. до н.э. [Петренко, 1978, с. 55].
Е.С. Нефедова свой тип 8 относит к тому же времени - IV-III вв. до н.э., но считает, что браслеты гальштатско-латенского круга бытуют довольно длительное время, при этом не слишком сильно меняя форму. Поэтому, собственно, форма браслета не является достаточной для датировки [Нефедова, 1992, с. 27].

С.В. Полин, проанализировав погребальные комплексы, содержавшие подобные браслеты, корректирует датировку Е.С. Нефедовой, ограничивая ее пределами первой половины - третьей четверти IV в. до н.э. [Полин, 2014, c. 73].

В.С. Синика датирует комплексы с рассматриваемыми браслетами так: ГлиноеВодовод, кург. 16, погр. 6 - третья четверть IV в. до н.э. - на основании совокупности амфорной тары (гераклейской и синопской), в том числе и клейменой, из основного для второй насыпи погребения [Синика и др., 2020, с. 199]; Глиное-Сад, кург. 8, погр. 5 - последняя четверть IV в. до н.э. - на основании бронзовых наконечников стрел и фибулы фракийского типа из кургана [Синика и др., 2018а, с. 90]; Глиное, кург. 71, погр. 1 - конец IV - первая четверть III в. до н.э. - на основании клейменой гераклейской амфоры [Тельнов и др., 2016 , с. 965]. Таким образом, все исследователи сходятся на датировке таких браслетов второй половиной IV - началом III в. до н.э.

Функциональное назначение рассматриваемых браслетов не оставляет сомнений. Bce три экземпляра из Глинянского могильника были найдены на костях рук женщин и ребенка. Такой же браслет в Крихана Веке 5/5 был надет на руку женского скелета вместе с браслетом другого типа [Ciobanu et al., 2019, p. 95, fig. 23].

\section{Кольца}

Одиночное кольцо было найдено в погребении Глиное-Водовод, кург. 7, погр. 2. Погребение скифское, впускное. Ребенок 89 лет. В норе, у западной стенки ямы, были обнаружены фрагменты кольиа [Синика и др., 2019, с. 369-372, рис. 4,3].

Кольцо бронзовое литое, круглое в сечении, с тремя овоидными одинарными выступами. Изделие фрагментировано. Диаметр кольца - около 2,1 см; диаметр внутренний - 
до 1,7 см. Сечение - около 2 мм. Размеры выступов: $7 \times 6 \times 5$ мм, 6,5 × 4,6 × 3,5 мм. Третий выступ сохранился частично (рис. 1,7 ).

Еще одно одиночное кольцо было найдено в погребении Глиное-Сад, кург. 8, погр. 2. Погребение скифское, впускное. На раздавленных костях черепа ребенка 6-9 месяцев лежало бронзовое кольияо [Синика и др., 2018 a, с. $82-84$, рис. 4,8$]$ (рис. 2,3).

Кольцо бронзовое, цельнолитое, округло-подовальное в сечении. С трех сторон украшено строенными шишечками. Диаметр кольца $-2,8 \times 2,65$ см. Размеры вместе с выступами - около $3 \times 3$ см. Сечение кольца $2-5,4 \times 4$ мм (рис. 1,8 ).

Цепочки из колец с шишечками были найдены в погребении Глиное-Водовод, кург. 14, погр. 3. Погребение скифское, основное. Погребенный (пол не определен, 2030 лет) лежал вытянуто на спине с разворотом на правый бок. Правая рука была слабо согнута в локте. Кисть левой руки - на крыле таза (рис. 2,1). В целом, инвентарь характерен для женского погребения. В области грудной клетки лежали строенные кольияа с шишечками. В районе живота находились сnаренные кольйа такого же типа и севернее левого крыла таза - еще одна парная иепочка таких колеи [Синика и др., 2018б, с. 39-44, рис. $33,1,35,8-10]$.

Двух- и трехзвенные иепочки из бронзовых цельнолитых колец с тремя розетками из сдвоенных шишечек по внешнему контуру. Ободок колец подовальный в сечении, местами - скругленно-подромбический, с выделенными внутренней и внешней гранями.

1. Двухзвенная цепочка из бронзовых цельнолитых колец обнаружена в заполнении. Длина цепочки - до 4,5 см (рис. 1,1).

- Кольио № 1. Диаметр кольца $2,25 \times 2,3$ см. Размеры вместе с выступами около 2,55 × 2,65 см. Сечение кольца $-2 \times 2-$ $2,8 \times 3,3$ мм. Размеры шишечек: $2,5 \times 3-$ $3 \times 3,5$ мм; толщина $-2,5-3$ мм; общая длина - до 7,4-8 мм.

- Кольияо № 2. Диаметр кольца $2,35 \times 2,42$ см. Размеры вместе с выступами около $2,57 \times 2,65$ см. Сечение кольца $2 \times 2,1-3,3 \times 4,4$ мм. Размеры шишечек: $3 \times 3,5-3,5 \times 4$ мм; толщина $-2-3,1$ мм; общая длина - до 8-8,5 мм.
2. Двухзвенная иепочка из бронзовых цельнолитых колец обнаружена у поясницы. Длина цепочки - до 4,5 см (рис. 1,2).

- Кольцьо № 1. Диаметр кольца $2,25 \times 2,4$ см. Размеры вместе с выступами около 2,6 $\times 2,9$ см. Сечение кольца - 2,8 $\times 2,8-$ $3,8 \times 4,5$ мм. Размеры шишечек: $2,5 \times 3,5-$ $4,3 \times 5$ мм; толщина - 2,2-4,3 мм; общая длина - до 7,5-8,4 мм.

- Кольио № 2. Диаметр кольца $2,3 \times 2,4$ см. Размеры вместе с выступами около $2,7 \times 3,2$ см. Сечение кольца $-3 \times 3,3-$ $4 \times 4,1$ мм. Размеры шишечек: $3,2 \times 4-$ $4,3 \times 5$ мм; толщина $-2,5 \times 4$ мм; общая длина - до 7,5-8,6 мм.

3. Трехзвенная цепочка из бронзовых цельнолитых колец обнаружена на груди справа. Длина цепочки - до 6,3 см (рис. 1,3).

- Кольияо № 1. Диаметр кольца $2,25 \times 2,35$ см. Размеры вместе с выступами около $2,55 \times 2,7$ см. Сечение кольца $2,5 \times 2,6-3,2 \times 4$ мм. Размеры шишечек: $3 \times 3,4-3,5 \times 3,5$ мм; толщина - 3-3,3 мм; общая длина - до 7,4-8 мм.

- Кольйо № 2. Диаметр кольца $2,35 \times 2,38$ см. Размеры вместе с выступами около $2,57 \times 2,73$ см. Сечение кольца $2,7 \times 3-3,6 \times 4,7$ мм. Размеры шишечек: $3,3 \times 3,7-3,5 \times 4$ мм; толщина - 2,5-3 мм; общая длина - до 8,2-8,6 мм.

- Кольцо № 3. Диаметр кольца $2,3 \times 2,37$ см. Размеры вместе с выступами около $2,52 \times 2,72$ см. Сечение кольца $2,6 \times 2,6-3 \times 3,9$ мм. Размеры шишечек: $2,6 \times 2,8-3,1 \times 3,4$ мм; толщина - 2,6-3,2 мм; общая длина - до 7,8-8,3 мм.

Колечки с шишечками, как одиночные, так и в составе цепочек, встречаются достаточно часто. Правда, существует внешне несколько сходная категория колец с выступами, которая, видимо, относится к деталям конской сбруи (рис. 5,1-2). Отличия состоят в форме выступов и/или их расположении -у колец-подвесок розеточки расположены по внешнему ободу кольца, а у колец из сбруи - на «лицевой» плоскости кольца. Кроме того, часто они снабжены характерными выступами со шляпками (видимо, для направления или фиксации ремешков) [Бидзиля и др., 1977, рис. 15,15,16]. На наших кольцах таких распределительных выступов нет. 
Близкой аналогией рассматриваемому кольцу с одинарными выступами является пара колец из погр. 1 кург. 4 у с. Ильинка [Плешивенко, 1991, с. 58 , рис. 3,9] (рис. 4,6). В том же кургане, в погр. 4, найдено было одиночное кольцо с тремя розеточками из спаренных выступов [Плешивенко, 1991, с. 68, рис. 9,5] (рис. 4,3). Одиночное кольцо с тройными розеточками находит аналогии в Капитановке, кург. 487, погр. 2 [Петренко, 1967, рис. 25,12] (рис. 4,4), и в Носаках, кург. 4, погр. 3 [Бидзиля и др., 1977, с. 114, рис. 19,12,15] (рис. 4,10-11). Наиболее приближенные географически аналогии найдены: в Чауше, кург. 4, погр. 1, - кольцо с тремя розеточками из сдвоенных шариков [Гудкова и др., 1981, с. 65, табл. LV,5] (рис. 4,5); в Градешке, кург. 7a, погр. 1, - точно такие же кольца образовывали трехзвенную цепочку [Гудкова, Суничук, 1984, с. 73, табл. 135,2-3] (рис. 4,9). Двухзвенная цепочка из таких колец с тремя розеточками также известна из могильника Муригиол [Бужор, 1958, с. 135, рис. 7,18$]$ (рис. 4,7). В Золотой Балке, кург. 13, погр. 5 , найдена цепочка из двух колец - одно кольцо с тремя одинарными выступами и другое кольцо - с тремя розетками из строенных шариков и петелькой [Полин, 2014, с. 73-74, рис. $39,3,5]$ (рис. 4,1-2).

В.Г. Петренко рассматривает такие кольца в категории «серьги», считая, что кольца с выступами подвешивались в виде амулетов к проволочным кольцевидным серьгам типов 2731. Об этом, по ее мнению, говорят петельки на некоторых из таких колец [Петренко, 1978, с. 3839 , табл. $23,24,26,16,23,27,45]$. Однако на сегодняшний день добавилось, как показано выше, много примеров находок таких колец в составе цепочек, а не серег. Самой интересной, на наш взгляд, является цепочка из Кириковки, кург. 12, где между двумя двухзвенными цепочками тоненьким, продетым сквозь нее ремешком крепилась крупная бусина из дымчатого хрусталя [Мельник, 1905, с. 715, рис. 119] (рис. 4,8). Данная находка, а также место в погребениях таких цепочек, на наш взгляд, говорят об использовании их в сложносоставных ожерельях.

В.Г. Петренко датирует появление подвесок с выступами в Левобережной лесостепи VI в. до н.э., а наибольшее их распространение - IV-III вв. до н.э. [Петренко, 1978, с. 39].
Могильник в урочище Носаки, где были найдены аналогичные кольца, датируется второй половиной IV в. до н.э. [Бидзиля и др., 1977, с. 64].

С.В. Полин приходит к выводу, что датировка всей группы таких колечек-подвесок Скифии (в частности, колец из Капитановки и Золотой Балки) твердо ограничивается IV в. до н.э. [Полин, 2014, с. 74-75].

По совокупности погребального инвентаря комплекс в Градешке может быть датирован первой половиной III в. до н.э., а погребение в Чауше - IV в. до н.э. (определение В.С. Синики).

В.С. Синика датирует погребение Глиное-Водовод, кург. 14, погр. 3 второй четвертью IV в. до н.э. на основании совокупности чернолаковой посуды из комплекса [Синика, Тельнов, 2020, с. 13]. Комплекс ГлиноеСад, кург. 8, погр. 2 датируется последней четвертью IV в. до н.э. на основании бронзовых наконечников стрел и фибулы фракийского типа из кургана [Синика и др., 2018a, с. 90]. А комплекс Глиное-Водовод, кург. 7, погр. 2 датируется на основании бронзовых наконечников стрел и совокупности данных о погребальном обряде из кургана концом IV - началом III в. до н.э. [Синика и др., 2019, с. 387]. Таким образом, датировка колец с выступами практически совпадает с датировкой браслетов такого же типа - IV - начало III в. до н.э.

\section{Заключительные положения}

Глинянские браслеты с выступами в виде розеток из двух, трех и четырех выпуклин изготовлены, видимо, методом литья по восковой модели. Учитывая небольшое количество браслетов такого типа в Северном Причерноморье, на наш взгляд, пока сложно делать однозначный вывод об их местном производстве. Все исследователи сходятся на датировке таких браслетов второй половиной IV началом III в. до н.э. Назначение рассматриваемых изделий не оставляет сомнений - их надевали на руки женщины и дети.

Датировка колец с одинарными, сдвоенными и строенными выступами практически совпадает с датировкой браслетов такого же типа - IV - начало III в. до н.э. Есть данные, позволяющие говорить об использовании их в сложносоставных ожерельях. 


\section{ИЛЛЮСТРАЦИИ}

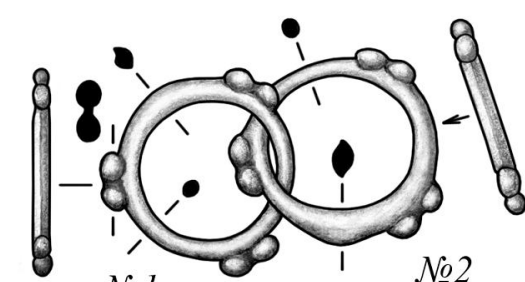

№l
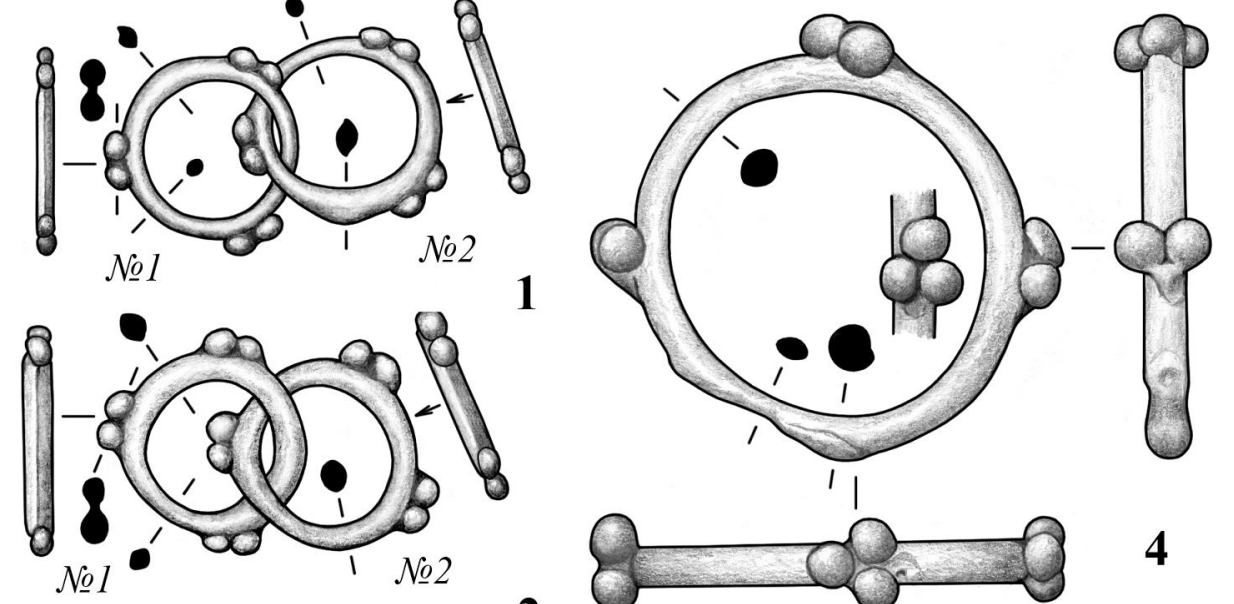

2

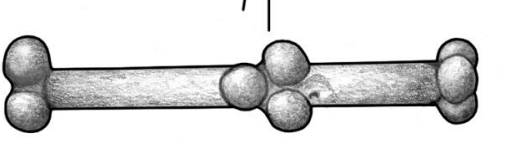

4

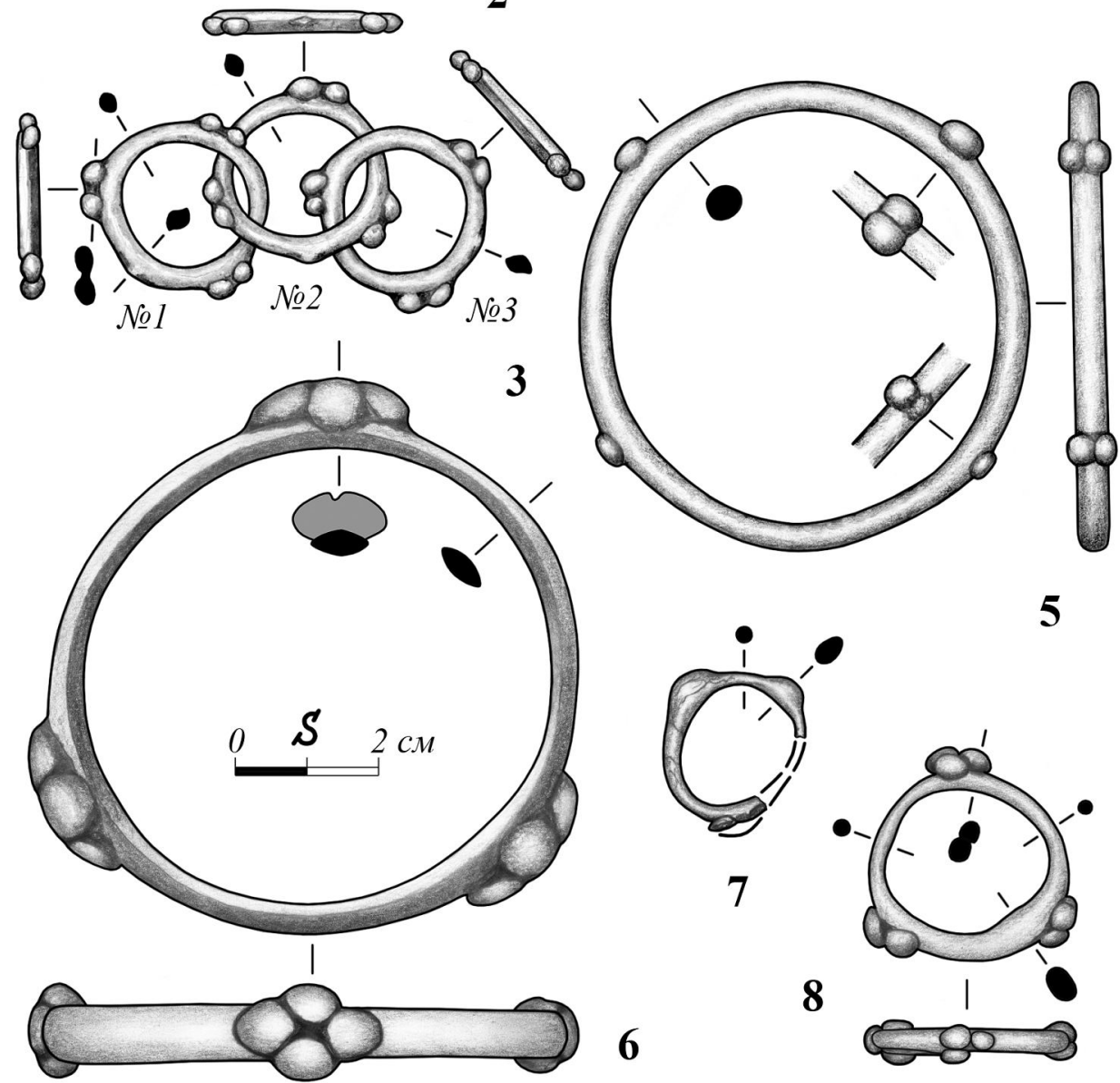

Рис. 1. Кольца и браслеты латенского стиля из погребений Глинянского могильника (рис. С.Д. Лысенко):

1-3 - Глиное-Водовод, кург. 14, погр. 3; 4 - Глиное-Водовод, кург. 16, погр. 6; 5 - Глиное, кург. 71, погр. 1; 6 - Глиное-Сад, кург. 8, погр. 5;

7 - Глиное-Водовод, кург. 7, погр. 2; 8 - Глиное-Сад, кург. 8, погр. 2

Fig. 1. Rings and bracelets of the La-Ten style from the burials of the Glinoe cemetery (figures by S.D. Lysenko):

1-3 - Glinoe-Vodovod group, kurgan 14, burial 3; 4- Glinoe-Vodovod group, kurgan 16, burial 6;

5 - Glinoe, kurgan 71, burial 1; 6 - Glinoe-Sad group, kurgan 8, burial 5;

7 - Glinoe-Vodovod group, kurgan 7, burial 2; 8 - Glinoe-Sad group, kurgan 8, burial 2 


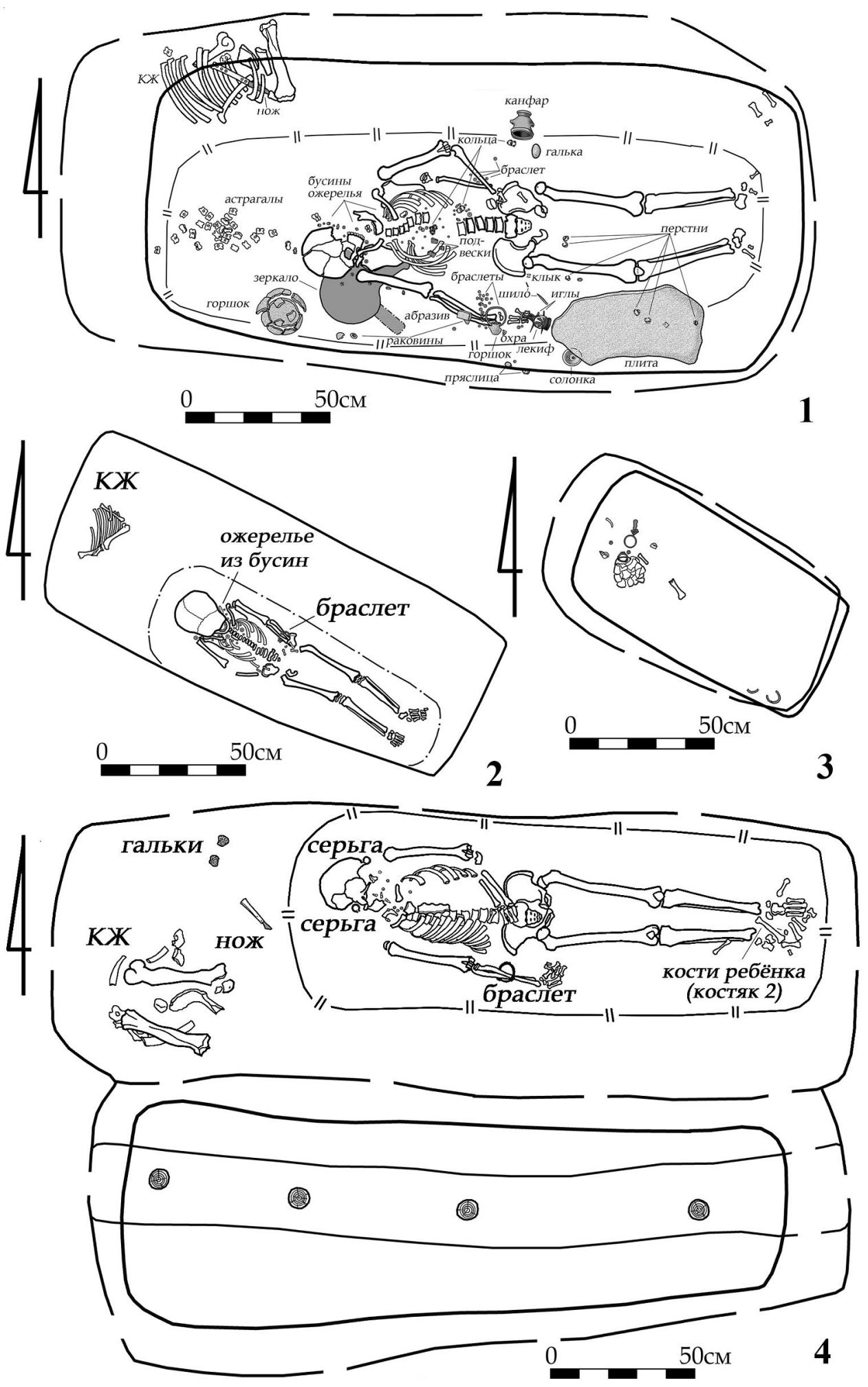

Рис. 2. Планы погребений с браслетами латенского стиля Глинянского могильника (чертежи погребений выполнены С.Н. Разумовым):

1 - Глиное-Водовод, кург. 14, погр. 3; 2 - Глиное-Водовод, кург. 16, погр. 6; 3 - Глиное-Сад, кург. 8, погр. 2; 4 - Глиное-Сад, кург. 8, погр. 5

Fig. 2. Plans of the burials with bracelets of the La-Tene style from the Glinoe cemetery (drawings by S.N. Razumov):

1 - Glinoe-Vodovod group, kurgan 14, burial 3;2 - Glinoe-Vodovod group, kurgan 16, burial 6; 3 - Glinoe-Sad group, kurgan 8, burial 2; 4 - Glinoe-Sad group, kurgan 8, burial 5 
S.S. Lysenko. Scythian Bracelets and Rings with Protrusions from the Cemetery Near Glinoe Village
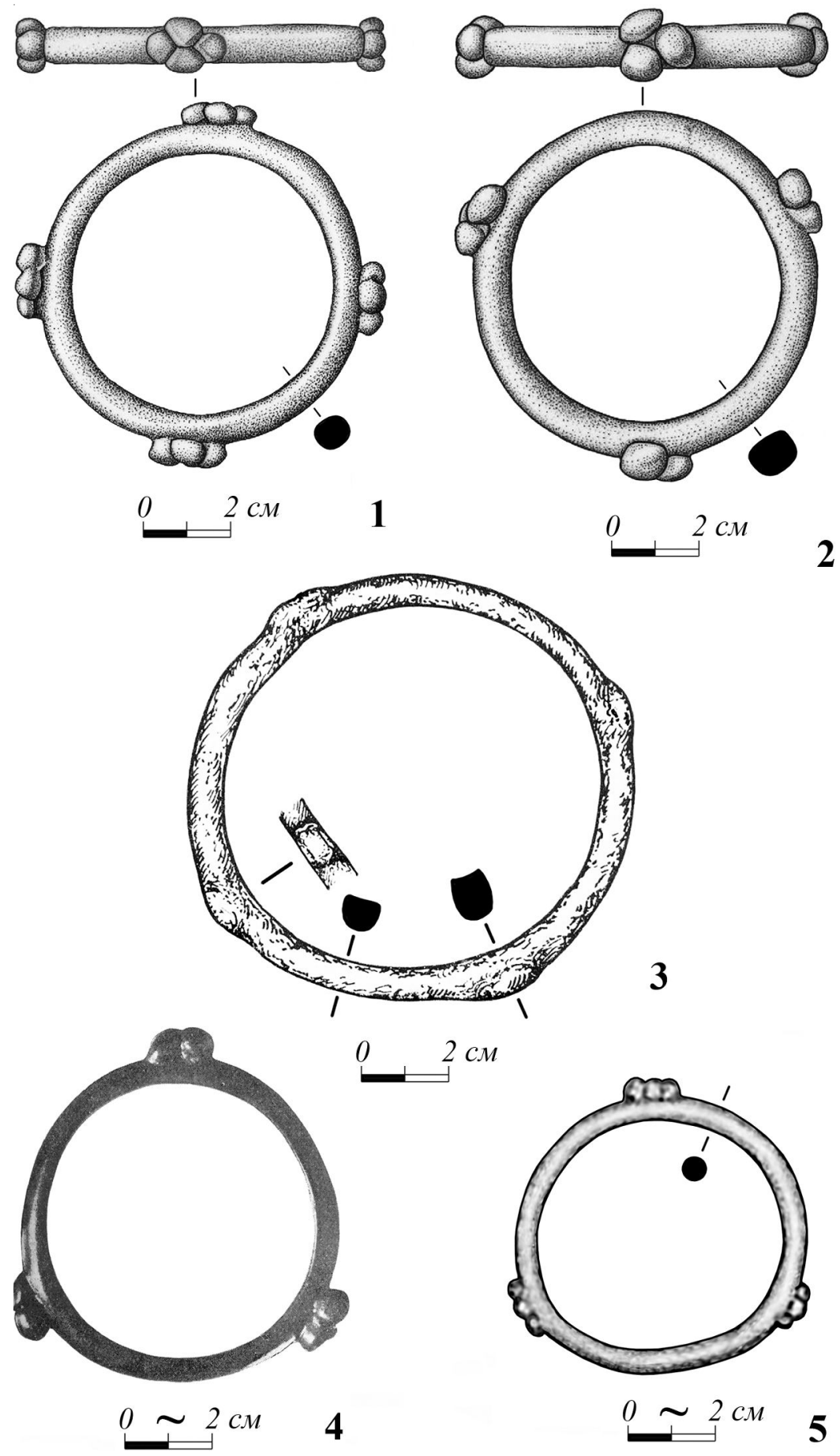

Рис. 3. Браслеты латенского стиля:

1-2 - Крихана Веке, кург. 5, погр. 5 (по: [Ciobanu et al., 2019, fig. 25,1]);

3 - совхоз «Красный Перекоп», кург. 23, погр. 1 (по: [Петренко, 1978, табл. 44,15]);

4 - Муригиол (по: [Бужор, 1958, рис. 7,11]); 5 - Окна Сибиулуй (по: [Zirra, 1971, abb. 3,11])

Fig. 3. La-Tene style bracelets:

1-2 - Krihana-Veke, kurgan 5, burial 5 (after: [Ciobanu et al., 2019, fig. 25,1];

3 - sovkhoz Krasnyy Perekop, kurgan 23, burial 1 (after: [Petrenko, 1978, tab. 44,15]);

4 - Murigiol (after: [Bujor, 1958, fig. 7,11]); 5 - Ocna Sibiului (after: [Zirra, 1971, abb. 3,11]) 

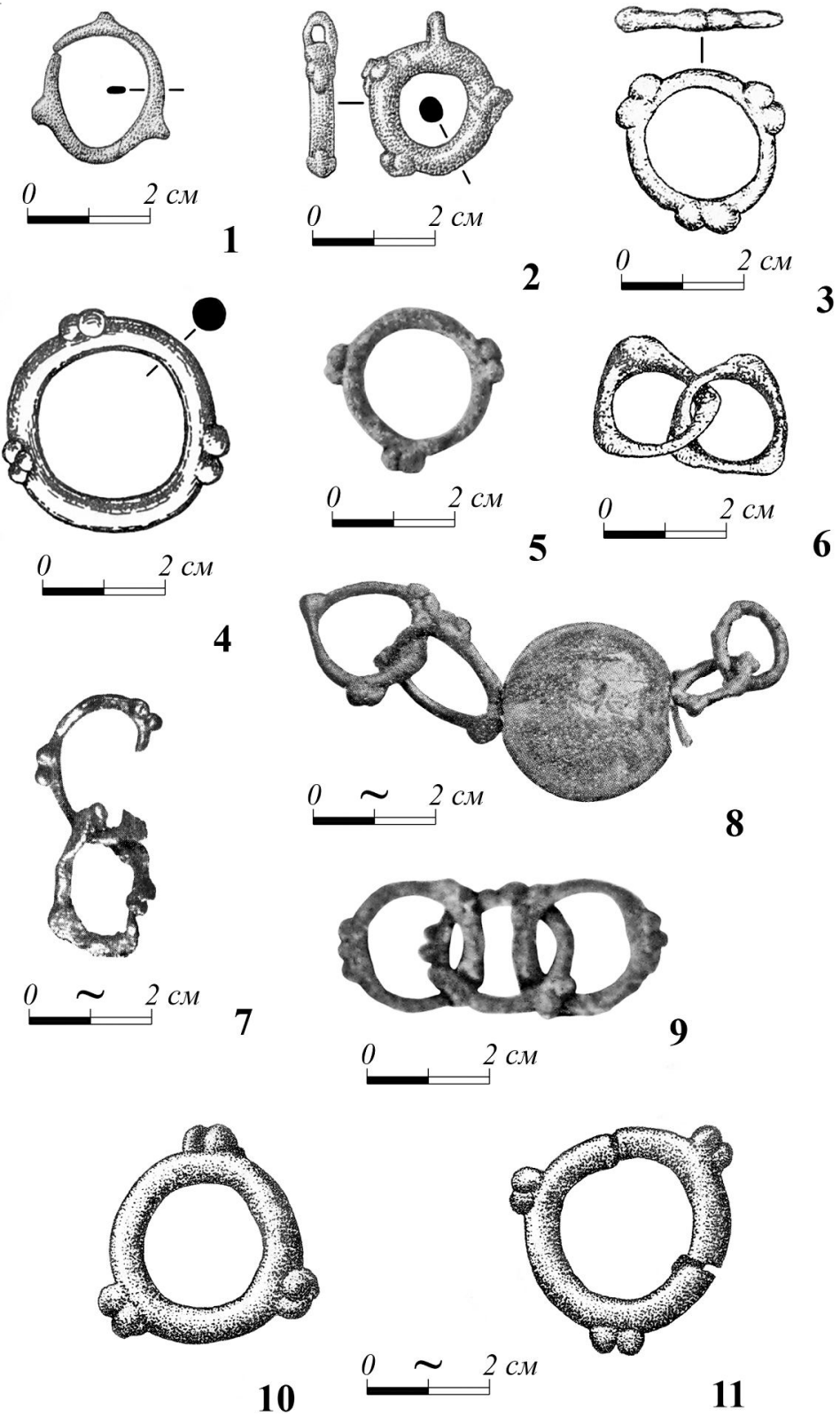

Рис. 4. Кольца латенского стиля:

1-2 - Золотая Балка, кург. 13, погр. 5 (по: [Полин, 2014, рис. 39,3]); 3 - Ильинка, кург. 4, погр. 4 (по: [Плешивенко, 1991, рис. 9,5]);

4 - Капитановка, кург. 487, погр. 2 (по: [Петренко, 1967, табл. 25,12]);

5 - Чауш, кург. 4, погр. 1 (по: [Гудкова и др., 1981, табл. LV,5]);

6 - Ильинка, кург. 4, погр. 1 (по: [Плешивенко, 1991, рис. 3,9]);

7 - Муригиол (по: [Бужор, 1958, рис. 7,18]); 8 - Кириковка, кург. 12 (по: [Мельник, 1905, рис. 119]);

9 - Градешка, кург. 7а, погр. 1 (по: [Гудкова, Суничук, 1984, табл. 135,2-3]);

10-11 - Носаки, кург. 4, погр. 3 (по: [Бидзиля и др., 1977, рис. 19,12,15])

Fig. 4. La-Tene style rings:

1-2 - Zolotaya Balka, kurgan 13, burial 5 (after: [Polin, 2014, fig. 39,3]);

3 - Ilyinka, kurgan 4, burial 4 (after: [Pleshivenko, 1991, fig. 9,5]);

4 - Kapitanovka, kurgan 487, burial 2 (after: [Petrenko, 1967, tab. 25,12];

5 - Chaush, kurgan 4, burial 1 (after: [Gudkova et al., 1981, tab. LV,5]);

6 - Ilyinka, kurgan 4, burial 1 (after: [Pleshivenko, 1991, fig. 3,9]);

7 - Murigiol (after: [Bujor, 1958, Fig. 7,18]); 8 - Kirikovka, kurgan 12 (after: [Melnik, 1905, fig. 119]);

9 - Gradeshka, kurgan 7a, burial 1 (after: [Gudkova, Sunichuk, 1984, tab. 135,2-3]);

10-11 - Nosaki, kurgan 4, burial 3 (after: [Bidzilya et al., 1977, fig. 19,12,15]) 
S.S. Lysenko. Scythian Bracelets and Rings with Protrusions from the Cemetery Near Glinoe Village
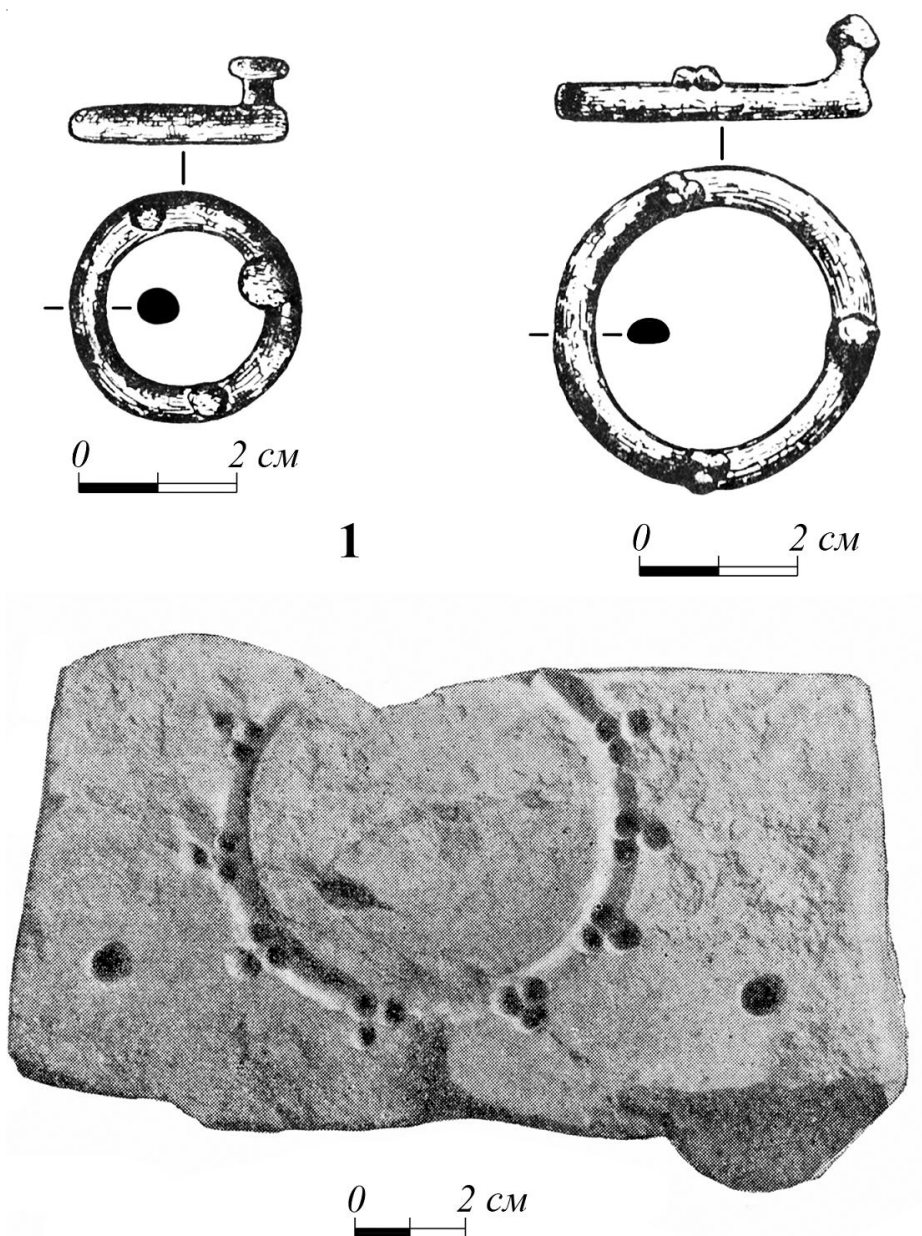

3

Рис. 5. Упряжные кольца с выступами:

1 - Бобрица, кург. 31 (по: [Петренко, 1967, табл. 25,8]); 2 - Кошеватое, курган (по: [Петренко, 1967, табл. 25,9]); 3 - литейная форма для отливки браслета латенского стиля из Ольвии (по: [Фурманська, 1958, табл. IV,5])

Fig. 5. Rings with protrusions from the horse harness:

1 - Bobritsa, kurgan 31 (after: [Petrenko, 1967, tab. 25,8]); 2 - Koshevatoe, kurgan (after: [Petrenko, 1967, tab. 25,9]); 3 - casting mold for casting bracelets of the La-Tin style from Olbia (after: [Furmanska, 1958, tab. IV,5]) 


\section{СПИСОК ЛИТЕРАТУРЫ}

Бидзиля В. И., Болтрик Ю. В., Мозолевский Б. Н., Савовский И. П., 1977. Курганный могильник в урочище Носаки // Курганные могильники Рясные Могилы и Носаки. Киев : Наукова думка. С. 61-158.

Бужор Э., 1958. О Гето-дакийской культуре в Муригиоле // Dacia. Nouvelle série, T. II. Bucarest : Institut d'archéologie. C. 125-141.

Гудкова А. В., Добролюбский А. О., Тощев Г. Н., Фокеев М. М., 1981. Отчет о работе Измаильской новостроечной экспедиции Института археологии АН УССР в 1981 г. // Научный архив Института археологии НАН Украины. № 1981/1. 94 с., 80 табл.

Гудкова А. В., Суничук Е. Ф., 1984. Полевой отчет Орловского курганного отряда Буджакской археологической экспедиции 1984 г. // Научный архив Институга археологии НАН Украины. № 1984/3a. 123 с., 190 табл.

Мельник Е., 1905. Дневник раскопок. Курганы близ с. Кириковки // Труды ХІІ Археологического съезда. Т. 1. М. C. $673-743$.

Нефедова Е. С., 1992. К вопросу о браслетах латенского стиля // Проблемы хронологии латена и римского времени. СПб. : Ойум. С. 21-34.

Петренко В. Г., 1967. Правобережье Среднего Приднепровья в V-III вв. до н.э. САИ. Вып. Д1-4. М. : Наука. $180 \mathrm{c}$.

Петренко В. Г., 1978. Украшения Скифии VII-ІІІ вв. до н.э. САИ. Вып. Д4-5. М. : Наука. 144 с.

Плешивенко А. Г., 1991. Скифский курган у Белозерского лимана // Курганы степной Скифии. Киев : Наукова думка. С. 53-72.

Полин С. В., 2014. Скифский Золотобалковский курганный могильник V-IV вв. до н.э. на Херсонщине. Киев : Изд. Олег Филюк. 776 с.

Синика В. С., Тельнов Н. П., Лысенко С. Д., 2018а. Скифский курган 8 группы «Сад» на левобережье Нижнего Днестра // Вестник Нижегородского университета им. Н. И. Лобачевского. № 2. С. 78-93.

Синика В. С., Тельнов Н. П., Разумов С. Н., Лысенко С. Д., Лысенко С. С., Симоненко С. О., 2018б. Отчет о работах Днестровской археологической экспедиции по исследованию курганов у с. Глиное Слободзейского района в 2018 году // Архив Музея археологии Приднестровья ПГУ им. Т.Г. Шевченко. № 21.256 с.

Синика В. С., Лысенко С. Д., Тельнов Н. П., Разумов С. Н., 2019. Скифский курган 7 группы «Водовод» в Нижнем Поднестровье // Stratum plus. № 3. С. 365-390.

Синика В. С., Иващенко М. В., Лысенко С. Д., 2020. Случай синхронизации гераклейской и синопских клейменых амфор в скифском погребальном комплексе IV в. до н. э. на Нижнем Днестре // Stratum plus. № 6. C. 191-202.

Синика В. С., Тельнов Н. П., 2020. Чернолаковые сосуды из скифских погребений IV в. до н. э. в Нижнем Поднестровье (по материалам раскопок 2015, 2016 и 2018 гг.) // Русин. № 59. С. 10-20

Тельнов Н. П., Четвериков И. А., Синика В. С., 2016. Скифский могильник III-ІІ вв. до н.э. у с. Глиное. Тирасполь : Stratum plus. $1096 \mathrm{c}$.

Фурманська А.І., 1958. Ливарні форми з розкопок в Ольвії // Археологічні пам'ятки Української Радянської Соціалістичної Республіки. Т. 7. С. 40-60.

Ciobanu I., Simalcsik A., Bejenaru L., Pîrnău R., Agulnicov S., Popovici S., 2019. Onsiderații preliminare privind cercetările arheologice şi interdisciplinare de la Crihana Veche (raionul Cahul). Campaniile 2016 şi 2017 // Arheologia preventivă în Republica Moldova. Vol. IV. Chişinău: Agenția Națională Arheologică. P. 71-118.

Glodariu I., 1984. „Brăț̆ările” cu nodozități Latene târzii // Dacia. Nouvelle série. T. XXI. Bucarest : Institut d'archéologie. P. 63-79.

Zirra V.I., 1971. Beitrăge zur kenntnis deskeltischen Latine in Rumânien // Dacia. Nouvelle série. T. XV. Bucarest : Institut d'archéologie. P. 171-238.

\section{REFERENCES}

Bidzilia V.I., Boltrik Iu.V., Mozolevskiy B.N., Savovskiy I.P., 1977. Kurgannyy mogilnik v urochishche Nosaki [Kurgan Cemetery in the Nosaki Tract]. Kurgannye mogilniki Riasnye Mogily i Nosaki [Kurgan Cemeteries Riasnye Mogily and Nosaki]. Kiev, Naukova dumka Publ., pp. 61-158. 
Buzhor E., 1958. O Geto-dakiiskoy kulture v Murigiole [On the Geto-Dacian Culture in Murigiol]. Dacia. Nouvelle série, T. II. Bucarest, Institut d'archéologie, pp. 125-141.

Gudkova A.V., Dobroliubskiy A.O., Toshchev G.N., Fokeev M.M., 1981. Otchet o rabote Izmailskoy novostroechnoy ekspeditsiy Instituta arkheologii AN USSR v 1981 g. [Report on the Work of the Izmail Newbuilding Expedition of the Institute of Archeology of the Academy of Sciences of the Ukrainian SSR in 1981]. Nauchnyy arkhiv Instituta arkheologii NAN Ukrainy, № 1981/1. 94 p., 80 fig.

Gudkova A.V., Sunichuk E.F., 1984. Polevoy otchet Orlovskogo kurgannogo otryada Budzhakskoy arkheologicheskoy ekspeditsii 1984 g. [Field Report of the Orlov Kurgan Detachment of the Budzhak Archaeological Expedition in 1984]. Nauchnyy arkhiv Instituta arkheologii NAN Ukrainy, № 1984/3a. 123 p., 190 fig.

Mel'nik E., 1905. Dnevnik raskopok. Kurgany bliz s. Kirikovki [Excavation Diary. Kurgans near the Kirikovka Village]. Trudy XII Arkheologicheskogo s'ezda [Proceedings of the $12^{\text {th }}$ Archaeological Congress]. Vol. 1. Moscow, pp. 673-743.

Nefedova E.S., 1992. K voprosu o brasletakh latenskogo stilya [On the Issue of La-Tten Style Bracelets]. Problemy khronologii latena i rimskogo vremeni [Problems of La-Ten and Roman Time Chronology]. Saint-Petersburg, Oium Publ., pp. 21-34.

Petrenko V.G., 1967. Pravoberezh'e Srednego Pridneprovia v V-III vv. do n. e. [The Right Bank of the Middle Dnieper in the $5^{\text {th }}-3^{\text {rd }}$ Centuries BC.]. Svod Arkheologicheskih Istochnikov, iss. Д1-4. Moscow, Nauka Publ. $180 \mathrm{p}$.

Petrenko V.G., 1978. Ukrasheniya Skifii VII-III vv. do n. e. [Adornments of Scythia of the $7^{\text {th }}-3^{\text {rd }}$ Centuries BC.]. Svod Arkheologicheskih Istochnikov, iss. Д4-5. Moscow, Nauka Publ. 144 p.

Pleshivenko A.G., 1991. Skifskiy kurgan u Belozerskogo limana [Scythian Kurgan near Belozersky Estuary]. Kurgany stepnoy Skifii [Kurgans of Steppe Scythia]. Kiev, Naukova dumka Publ., pp. 53-72.

Polin S.V., 2014. Skifskiy Zolotobalkovskiy kurgannyy mogilnik V-IVvv. do n.e. na Khersonshchine [Scythian Zolotobalkovskiy Cemetery of the $5^{\text {th }}-4^{\text {th }}$ Centuries BC in the Kherson Region]. Kiev, Izdatel Oleg Filiuk Publ. 776 p.

Sinika V.S., Telnov N.P., Lysenko S.D., 2018a. Skifskiy kurgan 8 gruppy Sad na levoberezh'e Nizhnego Dnestra [Scythian Barrow 8 of the "Garden" Group on the Left Bank of the Lower Dniester]. Vestnik Nizhegorodskogo universiteta im. N.I. Lobachevskogo [Vestnik of Lobachevsky University of Nizhni Novgorod], no. 2, pp. 78-93.

Sinika V.S., Telnov N.P., Razumov S.N., Lysenko S.D., Lysenko S.S., Simonenko S.O., 2018b. Otchet o rabotakh Dnestrovskoy arkheologicheskoy ekspeditsii po issledovaniyu kurganov u s. Glinoe Slobodzeyskogo rayona v 2018 godu [Report on the Work of the Dniester Archaeological Expedition about the Study the Barrows near the Glinoe Village, Slobodzeya District in 2018]. Arkhiv Muzeya arkheologii Pridnestrov'ya PGU im. T.G. Shevchenko, № $21.256 \mathrm{p}$.

Sinika V.S., Lysenko S.D., Telnov N.P., Razumov S.N., 2019. Skifskiykurgan 7 gruppy «Vodovod» v Nizhnem Podnestrove [Scythian Barrow 7 of the "Vodovod" Group in the Lower Dniester Region]. Stratum plus, no. 3, p. 365-390.

Sinika V.S., Ivaschenko M.V., Lysenko S.D., 2020. Sluchay sinhronizatsii gerakleyskoy i sinopskih kleymenyih amfor v skifskom pogrebalnom komplekse IV v. do n.e. na Nizhnem Dnestre [The Case of Synchronization of the Heraclea and Sinope Stamped Amphorae in a Scythian Grave of the $4^{\text {th }}$ Century BC from the Lower Dniester]. Stratum plus, no. 6, pp. 191-202.

Sinika V.S., Telnov N.P., 2020. Chernolakovye sosudy iz skifskikh pogrebeniy IV v. do n. e. v Nizhnem Podnestrov'e (po materialam raskopok 2015, 2016 i 2018 gg.) [Blackglazed Vessels from the Scythian graves of the $4^{\text {th }} \mathrm{c}$. BC In the Lower Dniester (based on excavations in 2015, 2016 and 2018)]. Rusin, no. 59, pp. 10-20.

Telnov N.P., Chetverikov I.A., Sinika V.S., 2016. Skifskii mogilnik III-II vv. do n. e. u s. Glinoe [Scythian Cemetery of the $3^{\text {rd }}-2^{\text {nd }}$ Centuries BC near the Glinoe Village].Tiraspol, Stratum plus. $1096 \mathrm{p}$.

Furmanska A.I., 1958. Lyvarni formy z rozkopok v Olvii [Casting Molds from Excavations in Olbia]. Arkheolohichni pam'iatky URSR [Archaeological Sites of the Ukrainian SSR]. Vol. 7, pp. 40-60.

Ciobanu I., Simalcsik A., Bejenaru L., Pîrnău R., Agulnicov S., Popovici S., 2019. Onsiderații preliminare privind cercetările arheologice şi interdisciplinare de la Crihana Veche (raionul Cahul). Campaniile 2016 şi 2017. Arheologia preventivă în Republica Moldova, vol. IV. Chişinău, Agenția Națională Arheologică, pp. 71-118.

Glodariu I., 1984. „Brățările” cu nodozități Latene târzii. Dacia. Nouvelle série, T. XXI. Bucarest, Institut d'archéologie, pp. 63-79.

Zirra V.I., 1971. Beitrăge zur kenntnis deskeltischen Latine in Rumânien. Dacia. Nouvelle série, T. XV. Bucarest, Institut d'archéologie, pp. 171-238. 


\section{Information About the Author}

Svetlana S. Lysenko, Candidate of Sciences (History), Researcher, Department of the Chalcolithic and the Bronze age, Institute of Archaeology, National Academy of Sciences of Ukraine, prosp. Geroev Stalingrada, 12, 04210 Kiev, Ukraine, aheron2000@yandex.ua, https://orcid.org/0000-0001-6713-6074

\section{Информация об авторе}

Светлана Станиславовна Лысенко, кандидат исторических наук, научный сотрудник отдела энеолита - бронзового века, Институт археологии Национальной академии наук Украины, просп. Героев Сталинграда, 12, 04210 г. Киев, Украина, aheron2000@yandex.ua, https://orcid.org/0000-0001-6713-6074 